\title{
Understanding the demand for REDD+ credits
}

\author{
TIMOTHY LAING ${ }^{1 *}$, LUCA TASCHINI ${ }^{1}$ AND CHARLES PALMER ${ }^{2}$ \\ ${ }^{1}$ London School of Economics and Political Science - Grantham Research Institute on Climate Change and the \\ Environment, London, $U K$ and ${ }^{2}$ London School of Economics and Political Science - Department of Geography \\ and Environment, London, $U K$
}

Date submitted: 7 July 2015; Date accepted: 19 May 2016; First published online 24 June 2016

THEMATIC SECTION

Forest Ecosystem Services

\section{SUMMARY}

Reducing emissions from deforestation and forest degradation (REDD+) has emerged as a potentially important component of the global policy mix to mitigate climate change. Against a background of increasing engagement between private sector entities and conservation organizations, private sector investment has emerged in REDD+. Despite slow developments at the international scale, there continues to be private sector interest in REDD+ and continued voluntary investments in REDD+ projects and initiatives. In order to better understand possible models for private sector engagement in REDD+, this study analysed the motivation of private sector stakeholders to engage in REDD+, the perception of the potential of REDD+, the critical obstacles to making REDD+ functional and how actors perceive themselves as part of future REDD+ scenarios. Based on interviews and a workshop with private sector actors, this study found that few expect a regulatory market for REDD+ to emerge and that credits from the voluntary market have to be tailored to specific needs. As a carbon offset, REDD+ provides insufficient motivation for investment, particularly if cheaper alternatives exist. Co-benefits such as biodiversity conservation and community development are more important when traditional corporate social responsibility motivations play a role. Project scale remains important not only for the fact that smaller projects are viewed as offering more visible benefits to stakeholders but also as a means of having more control over risks on the ground, posing a challenge for the design of jurisdictional REDD+. Moving towards supply chains that are free from deforestation offers an opportunity to tackle commodity-driven deforestation. While questions remain about how such an approach might be integrated into REDD+, it could help address a perceived gap between private sector understanding of the values of REDD+ and the risks associated with these values not arising - termed here as a 'missing middle'.

\footnotetext{
*Correspondence: Timothy Laing e-mail: timlaing31@gmail.com Supplementary material can be found online at http://dx.doi.org/10.1017/S0376892916000187
}

Keymords: carbon credits, offsetting, private sector engagement, REDD+

\section{INTRODUCTION}

The private sector has been traditionally viewed as being in conflict with organizations aiming to conserve the environment (Ehrenfeld 2003), but this has shifted with increasing engagement between private sector entities and conservation organizations (Rose \& Colchester 2004; Brockington \& Duffy 2011). The idea that firms can benefit society and the environment while making profits, has taken root; firms across the economy are being held accountable to this by conservation organizations and consumers (TEEB 2010; Robinson 2012).

Such corporate greening (the discovery by business of the cost, innovation and marketing advantages of improving environmental performance; Guziana 2013) has grown hand-inhand with the development of corporate social responsibility (CSR) programmes (Robinson 2012) that emerged as part of the corporate response to the challenges of environmental damage and climate change (Kolk \& Pinkse 2004) but are also often viewed as important marketing strategies (McWilliams \& Siegel 2001; Kitzmuller \& Shimshack 2012). Multi-national companies in particular have high incentives to engage in CSR as a way to reduce reputational risks (Ruggie 2008), with many seeing CSR programmes as effectively a licence to operate (Earthwatch et al. 2002).

Beyond CSR, opportunities have been identified for businesses to profit directly from engagement with conservation including the development of new markets for ecosystem services (TEEB 2010). Climate change policy, in particular, has witnessed great change in the 2000s, both with respect to regulations and markets established by governments, as well as voluntary initiatives and largely unregulated carbon offset markets. With tropical deforestation and forest degradation estimated to account for approximately $15 \%$ of global anthropogenic greenhouse gas emissions (van der Werf et al. 2009), stakeholders, ranging from international organizations and national governments to conservation organizations and the private sector, have sought to design strategies and policies for Reducing Emissions from Deforestation and Forest Degradation (REDD+).

REDD+ was first termed by the United Nations Framework on Climate Change (UNFCCC), with member 
countries initially focusing on it as an essential and timelimited contribution to mitigate the impacts of climate change. In its simplest form, governments and firms would reward tropical countries for reducing deforestation rates, receiving carbon credits in return. Cap-and-trade schemes like the European Union's Emissions Trading System (EU ETS) were touted as a way of establishing a price for forest carbon stocks. Since 2005, and in spite of initial high motivation and commitment from many stakeholders, including national governments, local communities, conservationist NGOs and the private sector (Palmer \& Engel 2009; Nhantumbo 2011), progress in REDD+ has been slow.

In mid-2015, the final framework for REDD+ suggested broad agreement in its overall scope, objectives, and monitoring, reporting and verification (MRV) (Meyer 2015). The scope of REDD+ has, however, increased dramatically from early proposals for a tool targeting reduced deforestation at project scale, funded by firms purchasing carbon credits, to potentially nation-wide programmes targeting deforestation, degradation and re-forestation, known as 'Jurisdictional and Nested REDD+' (JNR). Between 2005 and 2015, many policy initiatives and experiments have claimed the mantle of REDD+, at all scales, involving a range of stakeholders, from Norway's investments in national programmes in Indonesia (Lee \& Pistorius 2015), to Bosques Amazonicos (a Peruvian company) supporting organic certification of Brazil nuts in Madre de Dios (Peru) to encourage illegal gold miners to switch activities (IGES 2013). The critical need to stem tropical deforestation, whether for climate reasons or otherwise, is generally agreed upon, but concerns have been raised regarding the potential efficacy of REDD+ to reduce deforestation, including doubts over cost (Gregersen et al. 2010), infringements on local community rights (Larson 2011), and debates about how permanent reductions in deforestation might be achieved (Palmer 2011). This last issue is partially related to how REDD+ might be implemented on the ground, in terms of the policies, and extent to which these address underlying drivers of deforestation (Angelsen 2010).

Many scholars and practitioners nevertheless agree that to work in practice, REDD+ needs to be implemented at a scale that includes as much of the world's tropical forest as possible in order to prevent 'leakage', defined as reductions of carbon emissions in one place causing emissions in another (Atmadja \& Verchot 2011). Such scale would require a huge level of financing yet UNFCCC negotiations have failed to resolve the financing issue due to continuing disagreements among countries about who should pay and how (Leonard 2015). To date, finance flowing into REDD+ has been dominated by public funding from richer countries, significantly through Norway's agreements with Brazil, Indonesia and Guyana. The private sector has engaged with REDD+ for a wide range of voluntary reasons including offsetting of emissions, greening of supply chains and counterbalancing potential future risk (Corbera \& Schroeder 2011). Opportunities to profit have also arisen, for example from trading in REDD+ credits.
Private sector commitment to REDD+ has been strengthened through the New York Declaration on Forests, signed by 53 multinational companies and 37 governments, that pledges to halve deforestation by 2020 and end it by 2030 (UN 2014). A number of multi-nationals have recently committed to the goal of zero net deforestation, for example, Procter and Gamble have committed to eliminating deforestation across its palm oil supply chain by 2020 (Shankleman 2014).

Existing literature on private sector involvement in REDD + frames the issue as a mismatch between supply and demand. Conservation International (CI) estimated that REDD+ projects in existence represent more than three times current voluntary market demand (CI 2013), while the Global Canopy Programme (GCP) estimate demand for REDD+ could be as little as 3\% of supply between 2015 and 2020 (GCP et al. 2014). Despite the continued absence of REDD+ from existing regulatory schemes such as the EU ETS, the fact that the private sector continues to invest in REDD+ raises the question of what motivates them to do so.

The term 'REDD+' is nebulous and has been used to cover a range of activities concerning forests. Its scope has grown in the official UNFCCC proceedings from Reducing Emissions from Deforestation (RED) to include degradation (REDD) and then conservation of standing forests and reforestation (REDD+). REDD+ is, however, generally used as a catch-all term for projects and policies that are intended to avoid and reduce deforestation and forest degradation and contribute to regrowth of new forests. Since it has also grown in scale, initially focusing on project-based approaches before encompassing jurisdictional approaches at a regional or national scale, this study adopted a broad definition, that is, including projects and policies that fall both inside and outside the official UNFCCC process, and activities implemented at project and jurisdictional scales, funded both under regulatory schemes and through voluntary markets (Supplementary Material S1).

Drawing on data from interviews and a workshop with private sector actors, this study had a number of key objectives: it examines motivations of firms engaging in REDD+ for their investments and purchases of credits; decision-making procedures of those currently engaging in REDD+; barriers and risks that have prevented additional investors from engaging with REDD+; and, how private-sector stakeholders perceive REDD+ in the future.

\section{METHODOLOGY}

Views of private sector stakeholders participating in REDD+ were evaluated in a two-step process. In the first, semistructured one-to-one interviews, following interview guides (Supplementary Material S2), were conducted with 14 individuals. An initial mapping exercise was undertaken of key organizations involved in REDD+ located in Europe. The exercise focused on firms currently investing in REDD+, those investing in other types of carbon offsets, associations 
representing emitting industries and REDD+ investors, commodity purchasers and carbon-market traders. Contact was made with firms, organizations and individuals and interviews were scheduled. Further contacts were made and interviewed via snowball sampling.

Interviews were conducted between December 2013 and June 2014 at the London School of Economics (LSE) and across London. Four participants were not available to meet in person so phone and Skype interviews were conducted.

The focus was on firms that had either provided investment into REDD+ projects or purchased REDD+ credits, rather than project developers. Motivations and risks associated with developers are different from those of middle-men looking to purchase credits and sell them on, and different again from those looking to directly invest in REDD+ projects or purchase credits emanating from such projects. Therefore, unless explicitly stated the firms, or entities, referred to here are those investing in REDD+ or purchasing credits.

Questions focused on the potential interest of purchasers in REDD+, motivations of existing REDD+ purchasers, key decision-makers regarding offsetting in firms, time horizons of firms engaging (or not) in REDD+ and main barriers for engaging private sector finance in REDD+ (Supplementary Material S2).

In a second step a workshop was held under Chatham House rules at LSE in April 2014. A total of 19 participants were involved, drawn from the REDD+ working groups of the Carbon Market Investors Association (CMIA) and the International Emissions Trading Association (IETA). They included representatives of project developers, investors, international donors and a range of companies who provided legal and institutional support to REDD+ projects. While they shared a background similar to those selected for interview, they were mutually exclusive, in order to allow us to check the validity of hypotheses developed on the basis of interviews.

The workshop was structured around three main sessions focusing on: where does REDD+ stand today; barriers and risks for REDD+; and the future for REDD+ (Supplementary Material S3). Each session started with a brief presentation that raised findings from interviews, followed by open discussion to validate findings and raise fresh perspectives.

\section{RESULTS}

\section{Motivations of private sector stakeholders}

\section{Preparatory and pre-regulatory demand}

A key question asked of interviewees was their perception of motivations of existing REDD+ purchasers. Responses varied, but a conclusion from all interviewees was a dichotomy between those investing for purely voluntary reasons, and those anticipating REDD+ being used in regulatory markets. Interviews with two REDD+ market experts (and validated at the workshop) led to the determination of two different categories of investors in the latter area. The first were those who faced potential future regulatory obligations and were looking to engage with REDD+ in order to gain experience. It was the consensus of participants to the workshop that this type of demand had declined recently due to declining prospects for REDD+ in regulatory markets. It was raised, both in interviews with emitting industry associations and at the workshop, that for entities looking to meet regulatory targets, the main factor determining whether they should engage in offsetting or not was minimizing costs.

The second category of investors identified were those companies motivated by resale opportunities that investing in REDD+ might bring. A workshop participant suggested that this type of investor had also declined, not only due to the reduced short-term prospects for REDD+ in regulatory markets, but also due to the experiences of early investors in projects that were perceived to have failed.

\section{Corporate social responsibility and offsetting}

For those companies looking to engage in REDD+ for voluntary reasons the motivations discussed by REDD+ purchasing interviewees and at the workshop were markedly different from those of pre-regulatory entities. Discussions at the workshop can be succinctly summed up by the phrase used by a workshop participant when discussing the motivations for financing REDD+: 'it's all about the story', suggesting that what was crucial was the message that could be communicated to stakeholders. A workshop attendee with experience in marketing REDD+ credits, however, raised the cogent point that to a number of companies the story of REDD+ was currently unattractive. REDD+ was predominantly viewed as actors being paid to stop cutting down the rainforest. In the workshop, this prompted the question raised by one participant of "why should I pay someone to stop doing something?' In the discussions that followed participants reached the consensus that the idea of paying for something tangible, like building an eco-lodge, was more attractive. This moves away from the idea of REDD+ as an 'emission reduction story' - the traditional view as observed by a workshop participant, where REDD+ is perceived merely as a tool to offset emissions - towards the role of co-benefits, for example, biodiversity protection. While such co-benefits were initially viewed as 'the cherry on the top for REDD+' by workshop participants, that is, as an additional benefit above and beyond the planned objective, the discussion concluded that they should now be seen as playing a central role in investment decisions.

An existing REDD+ purchaser interviewee highlighted that for firms looking to engage as part of their CSR programmes, the relevance of projects to their overall strategic direction was also important, and it was this relevance that had helped determine the decision to invest in REDD+ in their organization. Such firms looked to projects that offered wide benefits, and fitted within their corporate strategies, including a consideration of their customers. For example, a key business sustainability leader interviewee revealed that REDD+ was 
of particular relevance to firms with supply chains extending into forest landscapes.

A more hands-on approach to REDD+, where investors engage directly with the project on the ground, was reported by two interviewees to have not only helped make REDD+ attractive but also enabled greater control over risk. For one interviewee, such an approach was motivating firms to make direct investments in organizations that developed REDD+ initiatives and projects. An example of this approach is Kering, a luxury goods company, investing into Wildlife Works, a REDD+ project developer (Supplementary Material S4).

With regard to the price sensitivity of CSR investors, in analysing interviews and results of the workshop, it became useful to differentiate between those seeking to use REDD+ credits for CSR only and those seeking to use it for carbon-neutral CSR (i.e., voluntarily offsetting a company's emissions). When the question regarding price sensitivity was raised at the workshop it was the consensus that prices did not seem to be important for the former, who were reported to often view the purchase of REDD+ credits, as described by one participant, as a 'charitable donation'. The latter group, however, tended to care more about prices; with the overall aim of offsetting their emissions as cheaply as possible. They were only willing to pay higher prices if projects were charismatic and generated wider public relations (PR) benefits. Such firms, one interviewee ventured, often purchased large volumes of cheap offsets in order to cover the majority of emissions (e.g., renewable energy or industrial gas destruction), and a small volume of relatively more expensive REDD + offsets with co-benefits.

\section{Other potential sources of demand}

New pockets of demand have begun to emerge with little or no regulation from government. Instead, they have developed as a result of direct or indirect action in the private sector, responding either to internal drivers, such as the desire to move towards green supply chains, or external private sectorled drivers, such as through sustainability indices.

Charitable donations were identified at the workshop as being targeted by REDD+ project developers. A number of large philanthropic foundations have already been active including the MacArthur Foundation and the Clinton Foundation ( $\mathrm{PwC}$ et al. 2011). For example, the latter has supported carbon monitoring in countries such as Guyana, while the MacArthur Foundation has a dedicated programme aiming to minimize deforestation in countries such as the Democratic Republic of Congo.

Other sources of demand for REDD+ identified by participants included incentives provided by sustainability targets, such as the Dow Jones Sustainability Index (DJSI), which evaluates the sustainability performance of the largest 2500 companies listed on the Dow Jones Global Total Stock Market Index.

In a discussion at the workshop a participant with experience in seeking new markets for REDD+ reported that they were investigating demand from companies potentially exposed to significant risk from their investments in carbonintensive assets that could become stranded if climate or energy regulation is tightened ('stranded assets'). The Generation Foundation identified market forces and sociopolitical pressure, along with regulation, as risks that could lead to significant stranding of fossil-fuel intensive assets (Generation Foundation 2013). Thus, large institutional investors, such as pension funds, could potentially diversify their portfolio away from companies holding potentially stranded assets, towards less risky opportunities that might thrive in a low-carbon future. The extent to which such opportunities might include REDD+ would depend on the barriers and risks encountered.

\section{Decision procedures, barriers and risks}

Different decision-making procedures and time horizons Participants were asked who the key REDD+ decisionmakers were in their respective firms. For those engaged in purchasing for CSR, decision-making generally lay with the CSR department, although in some instances decisionmaking went all the way to the CEO. Decision-making within CSR departments implies that finance for REDD+ comes out of general CSR budgets, and workshop participants highlighted the implications for the time horizon of those investments. With CSR budgets generally decided annually, investments often fluctuate from year-to-year. One participant responded (and there was general agreement subsequently) that, for voluntary purchases for CSR, horizons were not more than five years and often much shorter, suggesting a severe disconnect between financing for REDD+ and the typically longer timeframe of many REDD+ projects - rates of carbon sequestration determine that newly-planted forests take decades to reach maturity.

A new type of REDD+ project from which investors receive not only REDD + credits but also sustainably-sourced commodities was identified as a key potential future source of demand by a participant involved in developing projects, with longer time horizons than for CSR projects.

\section{Barriers, obstacles and risks}

Preparatory and pre-compliance market demand. Initially raised by an emitting industry association interviewee, and validated at the workshop, was the perception that many stakeholders, especially those anticipating regulatory markets, view a lack of regulatory frameworks and a lack of clarity regarding future regulations as a major barrier to investing in REDD+. Concerns were also raised by both potential purchasers (through emitting industry associations) and suppliers (through project developers at the workshop) over actual emergence of regulatory markets and REDD+'s eligibility into such markets. Emerging pilot institutions and procedures to register projects were perceived by project developers as being too bureaucratic, with a lack of clarity regarding the types of projects that would be allowed to generate credits and conditions under which they might be created. 
In addition, these investors were deemed by a project developer to be the most price sensitive and were also concerned with technical risks relating to REDD+ such as additionality, leakage and permanence (Palmer \& Engel 2009; Palmer 2011). It was the view of the same project developer that these risks were likely to be incorporated into criteria that would allow entry of REDD+ into regulatory markets and thus are likely to form part of the risk assessment of any regulatory purchasers.

Voluntary demand. Risks related to investments in the voluntary market were perceived, by both interviewees and at the workshop, to be different from regulatory investments. A major barrier, identified by a participant marketing REDD+ projects, was the current low profitability and expectations of future low profitability of REDD+ projects that generate revenues from the sale of credits. Price was deemed, in interviews with market experts, to be less important to investors with more general CSR motivations.

Project failure has great potential to damage the reputations of stakeholders involved, and has been a common theme of many REDD+ projects to date, for example the Ulu Masen REDD+ demonstration project in Aceh (Indonesia) (Supplementary Material S5). However, the private sector faces a challenge in measuring, quantifying and understanding reputational risks associated with $\mathrm{REDD}+$, particularly given the range of activities, initiatives, countries and contexts. Reducing reputational risk, or at least helping companies understand and quantify the risk could, in the view of participants, provide further impetus for companies to scale-up investment in REDD+. There are private sector institutions that already perform this role to some extent in the form of standards (e.g., The Verified Carbon Standard). However, at present these standards are extremely stringent, require huge effort and finance, and were highlighted by project developers as a major barrier of entry to the market.

Supply chain greening risks. The potential for REDD+ to find investment from companies looking to improve environmental performance in supply chains and promote sustainable agricultural activities, was raised by a commodity trader interviewee and repeated by others including existing REDD+ purchasers. A commodity market expert interviewee proposed a mechanism for firms to certify commodities as being 'deforestation free' via a trading mechanism with other firms, when zero deforestation sourcing is not possible within their own supply chains. At the workshop a REDD+ market expert participant reported that there have been some moves toward such tools through initiatives such as the Round Table on Sustainable Palm Oil. These, however, have encountered heavy criticism with accusations of weak standards and continued deforestation in members' concessions (Greenpeace 2013). The same market expert commented that more research was required to exploit the potentially large synergy between REDD+ and the move toward sustainable supply chains.
REDD+'s missing middle: the difficulty for private sector stakeholders to understand the complexity of REDD+

The workshop set out to understand two key aspects of the current market: the value or services that private sector actors obtain from REDD+ and the risks that these values or services may fail to emerge. Although participants recognized the importance of both, discussions also raised a further dimension: a broad lack of understanding of REDD + in the private sector inclusive of its values and risks, characterized here as REDD+'s 'missing middle'.

Informed by discussions at the workshop this missing middle is conceptualized as consisting of three elements: a lack of understanding of the values that REDD+ can bring to the private sector (highlighted above with regard to the lack of an attractive story for REDD+); a lack of understanding of the risks associated with REDD+ (demonstrated above in the discussion regarding difficulties in understanding and valuing reputational risks); and a lack of understanding regarding the mapping of risks on to values.

\section{Future scenarios for private sector involvement into REDD+}

In a discussion on the relative attractiveness of different scales of REDD+ projects a participant with experience of marketing REDD+ commented that CSR purchasers preferred 'small, nice, cuddly' projects, and the ownership, control and PR benefits these can offer in contrast to JNR. In the discussion that followed a market expert raised the perception that there were fears from some buyers of working too closely with national or regional governments due to issues of corruption, further reducing the attractiveness of JNR visà-vis project scale. Countering this, however, was the opinion raised by a project developer that firms wanted projects to be embedded in overall JNR frameworks, as these were more likely to reduce technical issues such as leakage.

Participants of the workshop were almost equally split over the future of REDD + . The first camp held that under clarified institutional settings and rules, REDD+ could eventually regain momentum, while the second expressed high uncertainty in this regard. Unless a robust framework for regulatory markets emerges, for instance through JNR, it was the perception of a market expert that private sector stakeholders preferred to participate in efforts to reduce emissions from deforestation and forest degradation in a narrower context. A point of consensus across the workshop, and also seen in interviews with market experts, is the likely move away from REDD + being the focal point of projects and activities, in the sense that the main motivation of firms investing was carbon credits. Instead, firms are looking for wider benefits from their investment, with multiple sources of income. There is an increasing focus on other benefits that arise from projects that aim to reduce deforestation and generate a return in other ways, such as agroforestry. 


\section{DISCUSSION AND CONCLUSION}

REDD+'s brief history has been marked by periods of optimism and pessimism. The current mood in the private sector is generally pessimistic, with doubts over the emergence of regulatory demand and supply of credits outstripping demand, reported both by participants and in the literature (CI 2013; Forest Trends 2014; GCP et al. 2014). Despite this general reporting of REDD+'s decline, our finding that resale opportunities for investors in REDD+ still exist offers hope and is mirrored by Forest Trends (2012), which found that almost half of buyers of forest carbon credits (including Afforestation and Reforestation credits through the Clean Development Mechanism (CDM)) were motivated by either resale or investment or for regulatory or pre-regulatory reasons. In the voluntary market, recent commitments by companies to reduce deforestation in supply chains (UN 2014) and innovative moves to market REDD+ as a tool to reduce investment risk offer potential. These voluntary actions raise the interesting proposition that at least some investment can be built on self-reinforcing action from within the private sector, with little or no government involvement.

Consistent with Corbera and Schroeder (2011), this study found that investors in REDD+ have different motivations, from pre-regulatory purchasers to those looking to voluntarily offset emissions, to those looking to reduce deforestation in supply chains. Firms seeking regulatory credits (or preregulatory experience) were more interested in obtaining low-cost options, whilst those purchasing for CSR were more interested in co-benefits (Forest Trends 2014) and the associated PR. Differentiated motivations for investing in REDD+ imply policymakers in REDD+ jurisdictions and project developers need to offer a range of different products, or at least to better understand the differentiated market.

A good understanding of the aims and function of REDD+, along with its values and risks, is lacking among many private sector investors. Both values and risks differ depending on motivations. But even where there is an awareness of risks, the private sector is unable to measure and quantify these. REDD+ lies outside the main activities of most firms, and if they are unable to understand or quantify specific risks of a particular project or initiative, they may be reluctant to invest. Improved understanding of the risks involved in different projects and initiatives might help direct capital to those with a better chance of reaching their aims. This could benefit REDD+ by helping to reduce demand for riskier projects and initiatives.

This lack of understanding regarding REDD+ (the 'missing middle') needs to be overcome if markets are to develop further. Helping to bridge this missing middle, aiding the private sector to understand the value that may arise from investing in REDD+ (and the positive impacts that REDD+ may bring to the environment and also to a company's image), and to understand (and quantify) the risks that may be encountered through such investment, could boost private sector investment. Given the multiplicity of REDD+ projects and initiatives, workshop participants unanimously agreed that there needs to be movement towards creating unified packages of information regarding REDD+.

In general, one of the greatest obstacles to innovation, especially in finance, is investors' natural resistance to change and new products often fail because investors are reluctant to shift strategy. This challenge has been met by other products in the environmental sphere such as Green Bonds (Climate Bonds Initiative 2015). Aversion to change can be even greater when investors are required to assess new products on the market themselves. Providing suitable, reliable and comparable information might remove at least one obstacle to greater engagement of private sector finance with REDD+.

Streamlining standards and the variety of certificates on offer could also reduce complexity for private sector decision-makers and might even help secure senior corporate backing. The recent growth in REDD+ standards and certificates mirrors the growth in certification schemes and eco-labels for timber that occurred in the 1990s. Indeed, some of the arguments for standardizing timber eco-labels and certification schemes, for instance, that the diversity of labels can be confusing for consumers (making it difficult to compare products' attributes) and weaken labels' credibility (Fischer et al. 2005), can also be applied to REDD+. Some degree of standardization, under the auspices of the UNFCCC, might help raise understanding of the potential values and benefits of REDD+ and assist in the understanding, measuring and quantification of the risks involved.

Given the scale of tropical deforestation, the current level of public and private investment to reduce it is tiny compared to what is required (CI 2013; GCP et al. 2014). This is the case irrespective of whether REDD+ is implemented in the form of positive incentives (like payments for environmental services) or reducing deforestation in supply chains so that inputs to production can be certified as being 'deforestation free'. Yet, at the scale of individual projects or jurisdictions such as Acre in Brazil (Climate Focus 2013), the private sector can potentially make a difference (Edwards et al. 2014). Indeed, where the private sector is part of the problem, in the sense of supplying commodities that drive forest conversion, it can be argued that it should, as quoted by a workshop participant, 'pay someone to stop doing something', becoming part of the solution. Supply chains that are free of deforestation would be a step in this direction and efforts should be made to integrate these with JNR.

For firms with operations not directly involved in deforestation, the problem with JNR is whether it will be sufficiently attractive and offer enough of a communicable storyline while providing sufficient finance to make it work. An institutional structure could be created that attracts a (capped) number of private sector partners to pool resources, at a size that allows each partner to obtain CSR benefits and retain sufficient ownership and control. Yet, the extent to which the private sector would be willing to get involved with a jurisdiction such as Acre in Brazil, whether individually or as part of a 'club', remains to be seen. It may require the 
incorporation of the benefits of REDD+ that appear to make it attractive to the voluntary market, such as co-benefits and associated PR. But then REDD+ policy would need to be designed to tackle multiple objectives - likely to be more challenging than tackling the single objective of reducing emissions from deforestation and forest degradation.

\section{ACKNOWLEDGEMENTS}

The authors would like to thank the participants of the study for their participation and many useful comments and suggestions on reviewing this paper. The authors would also like to thank Dr Murray Collins for his many comments and suggestions. The authors acknowledge the funding of NORAD via the EDF project to develop an Options Market and Complementary Financial Structures to Mobilize Private Capital for REDD+ and Manage Climate Policy Risks. The authors would also like to acknowledge the funding of the UK's Economic and Social Research Council via the ESRC Centre for Climate Change Economics and Policy.

\section{Supplementary material}

To view supplementary material for this article, please visit http://dx.doi.org/10.1017/S0376892916000187

\section{References}

Angelsen, A. (2010) Policies for reduced deforestation and their impact on agricultural production. Proceedings of the National Academy of Sciences 107(46): 19639-19644.

Atmadja, S. \& Verchot, L. (2011) A review of the state of research, policies and strategies in addressing leakage from reducing emissions from deforestation and forest degradation. Mitigation and Adaptation Strategies for Global Change 17(3): 311-336.

Brockington, D. \& Duffy, R. (2011) Capitalism and Conservation. London, UK: Wiley-Blackwell.

Climate Bonds Initiative (2015) Scaling up green bond markets for sustainable development [www document]. URL www.climatebonds.net/files/files/CBI-Guide-2015-finalweb.pdf

Climate Focus (2013) Acre, Brazil: subnational Leader in REDD+ [www document]. URL www.climatefocus.com/sites/ default/files/acre_brazil.pdf

CI (2013) REDD+ market: sending out an SOS [www document]. URL www.redd-monitor.org/wp-content/ uploads/2013/09/REDD-Market-SOS.pdf

Corbera, E. \& Schroeder, H. (2011) Governing and implementing REDD+. Environmental Science \& Policy 14: 89-99.

Earthwatch, IUCN \& WBCSD (2002) Business and Biodiversity: a Handbook for Corporate Action. Geneva, Switzerland: ATAR.

Edwards, R., Tepper, D. \& Lowery, S. (2014) Jurisdictional REDD+ bonds: leveraging private finance for forest protection, development and sustainable agriculture supply chains [www document]. URL www.forest-trends.org/documents/files/doc_4208.pdf

Ehrenfeld, D. (2003) Globalization: effects on biodiversity, environment and society. Conservation Society 1: 99-111.
Fischer, C., Aguilar, F., Jawahar, P. \& Sedjo, R. (2005) Forest Certification: Toward Common Standards? Washington, DC, USA: Resources for the Future.

Forest Trends (2012) Leveraging the Landscape: State of the Forest Carbon Markets 2012 [www document]. URL http://forest-trends.org/publication_details.php? publicationID $=3242$

Forest Trends (2014) Sharing the Stage: State of the Voluntary Carbon Markets 2014 [www document]. URL www.forest-trends.org/vcm2014.php

GCP, IPAM, FFI \& FI (2014) Stimulating interim demand for REDD+ emission reductions: the need for a strategic intervention from 2015 to 2020 [www document]. URL http://globalcanopy.org/sites/default/files/documents/ resources/IFF\%20report\%20Jan\%202014-Stimulating\% 20Interim\%20Demand\%20for\%20REDD\%2B.pdf

Generation Foundation (2013) Stranded carbon assets: why and how carbon risks should be incorporated in investment analysis [www document]. URL http://genfound.org/media/ pdf-generation-foundation-stranded-carbon-assets-v1.pdf

Greenpeace (2013) Certifying destruction: why consumer companies need to go beyond the RSPO to stop forest destruction [www document]. URL www.greenpeace.de/ files/publications/rspo-certifying-destruction.pdf

Gregersen, H., El Lakany, H., Karesnty, A. \& White, A. (2010) Does the Opportunity Cost Approach Indicate the Real Cost of REDD+? Rights and Realities of Paying for REDD+. Washington, DC, USA: Rights and Resources Institute.

Guziana, B. (2013) Corporate Greening: Product and Production Perspectives [www document]. URL www.diva-portal.org/ smash/get/diva2:613401/FULLTEXT03.pdf

IGES (2013) REDD Project in Brazil Nut Concessions in Madre de Dios [www document]. URL http://redd-database.iges.or.jp/ $\mathrm{redd} /$ download/project?id=99

Kitzmuller, M. \& Shimshack, J. (2012) Economic perspectives on corporate social responsibility. Fournal of Economic Literature 50(1): 51-84.

Kolk, A. \& Pinkse, J. (2004) Market strategies for climate change. European Management Fournal 22(3): 304-314.

Larson, A. (2011) Forest tenure reform in the age of climate change: lessons for REDD +. Global Environmental Change 21(2): 540-554.

Lee, D. \& Pistorius, T. (2015) The impacts of international REDD+ finance [www document]. URL www.unique-forst.de/ images/publications/vereinheitlicht/

ImpactsofInternationalREDDFinance.pdf

Leonard, S. (2015) The REDD+ Framework: finally complete after almost 10 years [www document]. URL http://blog.cifor.org/ 29000/the-redd-framework-finally-complete-after-almost-10years? $\mathrm{fnl}=\mathrm{en}$

McWilliams, A. \& Siegel, D. (2001) Corporate social responsibility: a theory of the firm perspective. The Academy of Management Reviem 26(1): 117-127.

Meyer, C. (2015) Three cheers for REDD+ and forests in the Paris Climate Agreement [www document]. URL http://blogs.edf.org/climatetalks/2015/12/15/three-cheersfor-redd-and-forests-in-the-paris-climate-agreement/

Nhantumbo, I. (2011) REDD+: a win-win deal is possible! [www document]. URL www.iied.org/redd-win-win-deal-possible

Palmer, C. (2011) Property rights and liability for deforestation under REDD+: implications for 'permanence' in policy design. Ecological Economics 70(4): 571-576. 
Palmer, C. \& Engel, S. (2009) Avoided Deforestation: Prospects for Mitigating Climate Change. London, UK: Routledge.

PwC, Winrock International, Climate Focus \& IUCN (2011) Funding for forests: UK Government support for REDD+ [www document]. URL www.gov.uk/government/uploads/ system/uploads/attachment_data/file/48074/1832-funding-

for-forests-uk-government-support-for-red.pdf

Robinson, J. (2012) Common and conflicting interests in the engagements between conservation organizations and corporations. Conservation Biology 26(6): 967977.

Rose, M. \& Colchester, M. (2004) Green corporate partnerships are they an essential tool in achieving the conservation mission or just a ruse for covering up ecological crimes? The Ecologist July/August: $30-33$.
Ruggie, J. (2008) Protect, respect and remedy: a framework for business and human rights. Innovations 3(2): 189-212.

Shankleman, J. (2014) P\&G pledges zero deforestation by 2020 [www document]. URL www.greenbiz.com/blog/2014/ 04/10/pg-pledges-zero-deforestation-2020

TEEB (2010) The Economics of Ecosystems and Biodiversity report for business - executive summary [www document]. URL www.teebweb.org/publication/teeb-for-business-executivesummary/

UN (2014) New York Declaration on Forests [www document]. URL www.un-redd.org/portals/15/documents/ ForestsDeclarationText.pdf

Van der Werf, G. R., Morton, D. C., DeFries, R. S., Olivier, J. G. J., Kasibhatla, P. S., Jackson, R. B. \& Randerson, J. T. (2009) $\mathrm{CO}_{2}$ emissions from forest loss. Nature Geoscience 2(11): 737-738. 